\title{
Antitumor Activity of 6-(cyclohexylamino)-1, 3-dimethyl-5(2-pyridyl)furo[2,3-d]pyrimidine-2, 4(1 H,3H)-dione and Its Ti(IV), Zn(II), Fe(III), and Pd(II) Complexes on K562 and Jurkat Cell Lines
}

\author{
Fahmideh Shabani, ${ }^{1}$ Shahriar Ghammamy, ${ }^{2}$ Khayroallah Mehrani, ${ }^{1}$ \\ Mohammad Bagher Teimouri, ${ }^{3}$ Masoud Soleimani, ${ }^{4}$ and Saeid Kaviani ${ }^{4}$ \\ ${ }^{1}$ Department of Chemistry, Islamic Azad University, Young Researchers club, Ardabil Branch, 56157-31567 Ardabil, Iran \\ ${ }^{2}$ Department of Chemistry, Faculty of Science, Imam Khomeini International University, 34149-16818 Ghazvin, Iran \\ ${ }^{3}$ Petrochemical Department, Iran Polymer and Petrochemical Institute, P.O. Box 14965-115, Tehran, Iran \\ ${ }^{4}$ Department of Hematology, Faculty of Medicine, Tarbiat Modarres University, P.O. Box 14115-318, Tehran, Iran
}

Correspondence should be addressed to Shahriar Ghammamy, shghamami@yahoo.com

Received 26 June 2008; Accepted 29 September 2008

Recommended by Lorenzo Pellerito

(6-(cyclohexylamino)-1,3-dimethyl-5(2-pyridyl)furo[2,3-d]pyrimidine-2,4(1H,3H)-dione) abbreviated as CDP was synthesized and characterized. $\mathrm{Ti}(\mathrm{IV}), \mathrm{Zn}(\mathrm{II}), \mathrm{Fe}(\mathrm{III})$, and $\mathrm{Pd}(\mathrm{II})$ metal complexes of this ligand are prepared by the reaction of salts of Ti(IV), $\mathrm{Zn}(\mathrm{II}), \mathrm{Fe}(\mathrm{III})$, and $\mathrm{Pd}(\mathrm{II})$ with CDP in acetonitrile. Characterization of the ligand and its complexes was made by microanalyses, FT-IR, ${ }^{1} \mathrm{H}$ NMR, ${ }^{13} \mathrm{C}$ NMR, and UV-Visible spectroscopy. All complexes were characterized by several techniques using elemental analysis (C, H, N), FT-IR, electronic spectra, and molar conductance measurements. The elemental analysis data suggest the stoichiometry to be 1:1 [M:L] ratio formation. The molar conductance measurements reveal the presence of 1:1 electrolytic nature complexes. These new complexes showed excellent antitumor activity against two kinds of cancer cells that are K562 (human chronic myeloid leukemia) cells and Jurkat (human T lymphocyte carcinoma) cells.

Copyright (C) 2008 Fahmideh Shabani et al. This is an open access article distributed under the Creative Commons Attribution License, which permits unrestricted use, distribution, and reproduction in any medium, provided the original work is properly cited.

\section{INTRODUCTION}

Nitrogen-containing ligands such as Schiff bases and their metal complexes played an important role in the development of coordination chemistry, resulting in an enormous number of publications, ranging from pure synthetic work to physicochemical [1] and biochemically relevant studies of metal complexes [2-6] and found wide range of applications. Other kinds of nitrogen-containing ligands are well-known pyrimidine systems such as purine analogues that exhibit a wide range of biological activities. Fused pyrimidine compounds are valued not only for their rich and varied chemistry, but also for many important biological properties. Among them, the furopyrimidine ring system, because of a formal isoelectronic relationship with purine, is of special biological interest. It has numerous pharmacological and agrochemical applications, namely, antimalarials, antifolates, and antivirus, as well as potential radiation protection agents. Recently, some furopyrimidines were shown to be potent vascular endothelial growth factor receptor2 (VEGFR2) and epidermal growth factor receptor (EGFR) inhibitors. Because of the importance of furo[2,3-d]pyrimidine derivatives, several methodologies for synthesizing them have already been developed. However, many of the synthetic protocols reported so far prolonged reaction times, harsh reaction suffer from disadvantages, such as relying on multistep reactions, needing anhydrous conditions, low yields, use of metal-containing reagents, and special instruments or starting materials. Therefore, the development of new and efficient methods for the preparation of furo[2,3-d]pyrimidine derivatives is still strongly desirable [7]. 


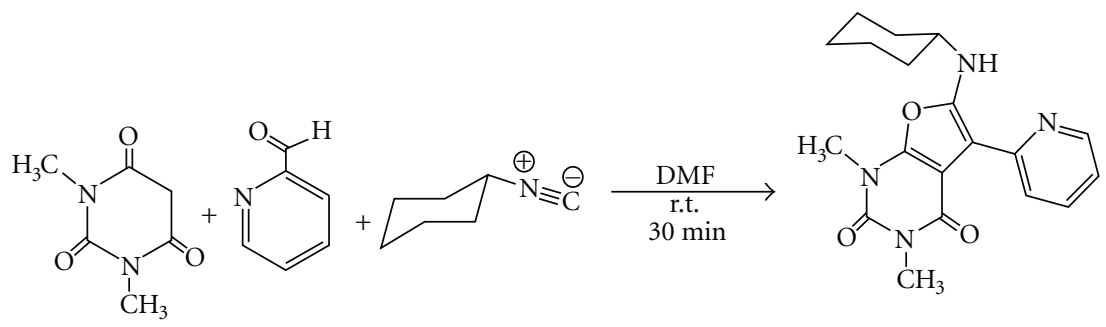

FIGURE 1: Synthesis route of CDP ligand.

Pyrimidines represent a very interesting class of compounds because of their wide applications in pharmaceutical, phytosanitary, analytical, and industrial aspects, for example, as antibacterial, fungicide [8], anti-inflammatory, antihelmintics, antitubercular, anti-HIV, antidegenerative and hypothermic activities [8], and herbicides [9], and have biological activities [10-14].

It has long been known that metal ions involve in biological processes of life and have been subject of interest. The modes of action of these metal ions are often complex but are believed to involve bonding to the heteroatoms of the heterocyclic residues of biological molecules, that is, proteins, enzymes, nucleic acids, and so forth [15].

From these points of view, it is interesting to study different types of transition metal complexes of these biologically active ligands. In this paper, the synthesis, characterization, and antitumor properties of a number of the first row transition metal complexes with one of the above ligands have been studied.

\section{MATERIALS AND METHODS}

\subsection{Chemicals and reagents}

$N, N^{\prime}$-dimethylbarbituric acid, 2-pyridinecarbaldehyde, titanium(VI) tetra fluoride, zinc(II) acetate dihydrate, iron(III) chloride hexahydrate, and palladium chlorides were Merck chemicals (Darmstadt, Germany) and were used without further purification. Organic solvents were reagent grade. Electronic spectra were recorded by Camspec UV-Visible spectrophotometer model Wpa bio Wave S2 100. The IR spectra were recorded using FT-IR Bruker Tensor 27 spectrometer. ${ }^{1} \mathrm{H}$-NMR and ${ }^{13} \mathrm{C}$-NMR were recorded on a Bruker AVANCE DRX 500 spectrometer. All the chemical shifts are quoted in ppm using the high-frequency positive convention; ${ }^{1} \mathrm{H}$ and ${ }^{13} \mathrm{C}$-NMR spectra were referenced to external SiMe ${ }_{4}$. The percent composition of elements was obtained from the Microanalytical Laboratories, Department of Chemistry, OIRC, Tehran.

\subsection{Cell culture}

The human chronic myeloid leukemia-K562 cell lineand the human $\mathrm{T}$ lymphocyte carcinoma-Jurkat cell line, used for treatment with the drugs, were provided. K562 and
Jurkat cells were grown at $37^{\circ} \mathrm{C}$ in an atmosphere containing 5\% $\mathrm{CO}_{2}$, with RPMI-1640 Medium HEPES Modification with L-glutamine and $25 \mathrm{mM}$ HEPES (Sigma-Aldrich Chemie $\mathrm{GmbH}$, Germany) supplemented with $10 \%$ heatinactivated fetal bovine serum (FBS) (Gibco, Carlsbad, Calif, USA), $2.7 \%$ sodium bicarbonate, and $500 \mathrm{mg} / \mathrm{L}$ ampicillin.

\section{EXPERIMENTAL}

\subsection{Synthesis of the CDP ligand}

To a solution of $N, N^{\prime}$-dimethylbarbituric acid $(0.78 \mathrm{~g}$, $5.0 \mathrm{mmol})$ and 2-pyridinecarbaldehyde $(0.54 \mathrm{~g}, 5.0 \mathrm{mmol})$ in DMF $(3 \mathrm{~mL})$ in a screw-capped vial was added cyclohexyl isocyanide $(0.55 \mathrm{~g}, 5.0 \mathrm{mmol})$ via a syringe and was shaken for 1 minute. The reaction mixture was then kept for about 30 minutes at room temperature $\left(25^{\circ} \mathrm{C}\right)$ and the completion of reaction was confirmed by TLC (EtOAc-hexane 1:2). Then, the resulting crystals were filtered and washed with diethyl ether $(20 \mathrm{~mL})$ to yield as light pink crystals $(1.42 \mathrm{~g}$, $80 \%)$. The dried product thus obtained showed a single spot on TLC and was pure enough for all analytical purposes [7] (see Figure 1).

\subsubsection{Analysis of CDP ligand}

Yield, $80 \%$. Mp $135.2-137.5^{\circ} \mathrm{C}$; Anal. Calcd. $\mathrm{C}_{19} \mathrm{H}_{21} \mathrm{~N}_{4} \mathrm{O}_{3}$ : C, 64.58; H, 5.94; N, 15.86. Found: C, 64.92; H, 6.29; N, 16.08 . ${ }^{1} \mathrm{H}$ NMR $\left(\mathrm{CDCl}_{3}\right): 4.40(1 \mathrm{H}, \mathrm{d}, \mathrm{NH}), 8.40$ and $7.60(1 \mathrm{H}$, $\mathrm{d}$, pyridine), 7.55 and $7.26(1 \mathrm{H}, \mathrm{d}$, pyridine $), 3.61(3 \mathrm{H}$, s, $\left.\mathrm{NCH}_{3}\right), 3.45\left(3 \mathrm{H}, \mathrm{s}, \mathrm{NCH}_{3}\right), 1.38(2 \mathrm{H}, \mathrm{m}$, cyclohexan $)$, $1.63(2 \mathrm{H}, \mathrm{m}$, cyclohexan $), 2.01(1 \mathrm{H}, \mathrm{m}$, cyclohexan $) ;{ }^{13} \mathrm{C}$ NMR $\left(\mathrm{CDCl}_{3}\right): 158.63\left(\mathrm{C}_{4}\right), 154.51(\mathrm{NCON}), 153.42\left(\mathrm{C}_{2}\right)$, $136.27\left(\mathrm{C}_{6}\right), 122.3\left(\mathrm{C}_{3}\right), 149.9,149.4,147.2$, and 118.4(pyridine), 52.34, 33.92, and 24.49(cyclohexan). IR $\left(\mathrm{KBr}, \mathrm{cm}^{-1}\right)$ : $3276 \mathrm{w}, 1664 \mathrm{w}, 1593 \mathrm{w}, 1449 \mathrm{~m}, 1266 \mathrm{w}, 1120 \mathrm{w}, 610$, and $742 \mathrm{~s}$. UV-vis (MeCN): $\lambda_{\max } 260 \mathrm{~nm}(\varepsilon 120), 336 \mathrm{~nm}(\varepsilon 110)$.

\subsection{Synthesis of the metal complexes: general method}

A solution of metal salt dissolved in acetonitrile was added gradually to a stirred acetonitrile solution of the ligand (CDP), in the molar ratio 1:1 (metal:ligand). The reaction mixture was further stirred for 2-4 hours to ensure the completion and precipitation of the formed complexes. 
The precipitated solid complexes were filtered and washed several times with $50 \%(\mathrm{v} / \mathrm{v})$ ethanol/water to remove any traces of the unreacted starting materials. Finally, the complexes were washed with diethyl ether and dried in vacuum desiccators over anhydrous $\mathrm{CaCl}_{2}$.

\subsubsection{Analysis of $\mathrm{Ti}\left(\mathrm{C}_{19} \mathrm{H}_{20} \mathrm{~N}_{4} \mathrm{O}_{3}\right) \mathrm{F}_{4}$}

Yield, 85\%. Anal. Calcd. $\mathrm{Ti}\left(\mathrm{C}_{19} \mathrm{H}_{20} \mathrm{~N}_{4} \mathrm{O}_{3}\right) \mathrm{F}_{4}$ : C, 47.89; $\mathrm{H}$, 4.20; N, 11.76. Found: C, 48.2; H, 4.37; N, 12.1. ${ }^{1} \mathrm{H}$ NMR (DMSO): 9(1H, d, pyridine $), 8.30(1 \mathrm{H}, \mathrm{d}$, pyridine $), 7.1(1 \mathrm{H}$, d, pyridine $), 3.53\left(3 \mathrm{H}, \mathrm{s}, \mathrm{NCH}_{3}\right), 3.01\left(3 \mathrm{H}, \mathrm{s}, \mathrm{NCH}_{3}\right), 1.08-$ $2.5\left(2 \mathrm{H}\right.$ and $1 \mathrm{H}, \mathrm{m}$, cyclohexan); IR $\left(\mathrm{KBr}, \mathrm{cm}^{-1}\right): 1689 \mathrm{~s}$, $1625 \mathrm{~m}, 1453 \mathrm{~m}, 1246 \mathrm{w}, 1153 \mathrm{w}, 774 \mathrm{~s}, 667 \mathrm{w}$, and $603 \mathrm{~s}$. UVvis $(\mathrm{MeCN}): \lambda_{\max } 377 \mathrm{~nm}(\varepsilon 54), 497 \mathrm{~nm}(\varepsilon 28)$.

\subsubsection{Analysis of $\mathrm{Zn}\left(\mathrm{C}_{19} \mathrm{H}_{20} \mathrm{~N}_{4} \mathrm{O}_{3}\right)(\mathrm{OAC})_{2}$}

Yield, 60\%. Anal. Calcd. $\mathrm{Zn}\left(\mathrm{C}_{19} \mathrm{H}_{20} \mathrm{~N}_{4} \mathrm{O}_{3}\right)(\mathrm{OAC})_{2}$ : C, 42.57; $\mathrm{H}, 3.73$; N, 10.45. Found: C, 43.5; H, 3.86; N, 10.82. ${ }^{1} \mathrm{H}$ NMR (DMSO): 8.30(1H, d, pyridine $), 8.06(1 \mathrm{H}, \mathrm{d}$, pyridine $)$, $7.5(1 \mathrm{H}, \mathrm{d}$, pyridine $), 3.3\left(3 \mathrm{H}, \mathrm{s}, \mathrm{NCH}_{3}\right), 3\left(3 \mathrm{H}, \mathrm{s}, \mathrm{NCH}_{3}\right), 1.2-$ $2.35\left(2 \mathrm{H}\right.$ and $1 \mathrm{H}, \mathrm{m}$, cyclohexan); IR $\left(\mathrm{KBr}, \mathrm{cm}^{-1}\right): 1691 \mathrm{~s}$, $1625 \mathrm{~m}, 1439 \mathrm{w}, 1246 \mathrm{w}, 1158 \mathrm{w}$, and $425 \mathrm{~s}$. UV-vis (MeCN): $\lambda_{\max } 262 \mathrm{~nm}(\varepsilon 110), 302 \mathrm{~nm}(\varepsilon 100), 344 \mathrm{~nm}(\varepsilon 78)$, and $415 \mathrm{~nm}(\varepsilon 60)$.

\subsubsection{Analysis of $\mathrm{Fe}\left(\mathrm{C}_{19} \mathrm{H}_{20} \mathrm{~N}_{4} \mathrm{O}_{3}\right) \mathrm{Cl}_{3}$}

Yield, 75\%. Anal. Calcd. $\mathrm{Fe}\left(\mathrm{C}_{19} \mathrm{H}_{20} \mathrm{~N}_{4} \mathrm{O}_{3}\right) \mathrm{Cl}_{3}$ : C, 44.32; $\mathrm{H}$, 3.88; N, 10.88. Found: C, 44.86; H, 4.18; N, $11.38 .{ }^{1} \mathrm{H}$ NMR (DMSO): 9.67(1H, d, pyridine), 9.02(1H, d, pyridine), 7.95 $(1 \mathrm{H}, \mathrm{d}$, pyridine $), 3.7\left(3 \mathrm{H}, \mathrm{s}, \mathrm{NCH}_{3}\right), 3.1\left(3 \mathrm{H}, \mathrm{s}, \mathrm{NCH}_{3}\right)$, $1.5-2.8\left(2 \mathrm{H}\right.$ and $1 \mathrm{H}, \mathrm{m}$, cyclohexan); IR $\left(\mathrm{KBr}, \mathrm{cm}^{-1}\right): 1600 \mathrm{w}$, $1546 \mathrm{w}, 1444 \mathrm{w}, 1154 \mathrm{~s}, 514 \mathrm{~m}$, and $599 \mathrm{~s}$. UV-vis (MeCN): $\lambda_{\max } 257 \mathrm{~nm}$ ( $\left.\varepsilon 280\right), 314 \mathrm{~nm}(\varepsilon 156), 363 \mathrm{~nm}$ ( $\left.\varepsilon 126\right), 440 \mathrm{~nm}$ ( $\varepsilon 60)$, and $494 \mathrm{~nm}(\varepsilon 28)$.

\subsubsection{Analysis of $\mathrm{Pd}\left(\mathrm{C}_{19} \mathrm{H}_{20} \mathrm{~N}_{4} \mathrm{O}_{3}\right) \mathrm{Cl}_{2}$}

Yield, 88\%. Anal. Calcd. $\mathrm{Fe}\left(\mathrm{C}_{19} \mathrm{H}_{20} \mathrm{~N}_{4} \mathrm{O}_{3}\right) \mathrm{Cl}_{3}$ : C, 43.07; $\mathrm{H}$, 3.77; N, 10.57. Found: C, 43.45; H, 3.95; N, 10.89. ${ }^{1} \mathrm{H}$ NMR (DMSO): 8.31(1H, d, pyridine), 7.55(1H, d, pyridine), 7.37 $(1 \mathrm{H}, \mathrm{d}$, pyridine $), 2.55\left(3 \mathrm{H}, \mathrm{s}, \mathrm{NCH}_{3}\right), 2.5\left(3 \mathrm{H}, \mathrm{s}, \mathrm{NCH}_{3}\right)$, 1.18-2.07(2 $\mathrm{H}$ and $1 \mathrm{H}, \mathrm{m}$, cyclohexan); IR $\left(\mathrm{KBr}, \mathrm{cm}^{-1}\right)$ : $1649 \mathrm{~s}, 1546 \mathrm{~m}, 1467 \mathrm{~m}, 1266 \mathrm{~m}, 1142 \mathrm{~m}$, and $495 \mathrm{~m}$. UVvis $(\mathrm{MeCN}): \lambda_{\max } 261 \mathrm{~nm}(\varepsilon 220), 307 \mathrm{~nm}(\varepsilon 130), 442 \mathrm{~nm}$ ( $\varepsilon 118)$, and $660 \mathrm{~nm}(\varepsilon 75)$.

\subsection{Cytotoxicity studies}

CDP ligand and $\mathrm{Ti}\left(\mathrm{C}_{19} \mathrm{H}_{20} \mathrm{~N}_{4} \mathrm{O}_{3}\right) \mathrm{F}_{4}, \quad \mathrm{Zn}\left(\mathrm{C}_{19} \mathrm{H}_{20} \mathrm{~N}_{4} \mathrm{O}_{3}\right)$ $(\mathrm{OAC})_{2}, \quad \mathrm{Fe}\left(\mathrm{C}_{19} \mathrm{H}_{20} \mathrm{~N}_{4} \mathrm{O}_{3}\right) \mathrm{Cl}_{3}$, and $\mathrm{Pd}\left(\mathrm{C}_{19} \mathrm{H}_{20} \mathrm{~N}_{4} \mathrm{O}_{3}\right) \mathrm{Cl}_{2}$ complexes arefive compounds which were assayed for cytotoxicity in vitro against K562 (human chronic myeloid leukemia) cells and Jurkat (human T lymphocyte carcinoma) cells.

The two cell lines were provided by the Pasteur Institute in Iran. The procedure for cytotoxicity studies was similar

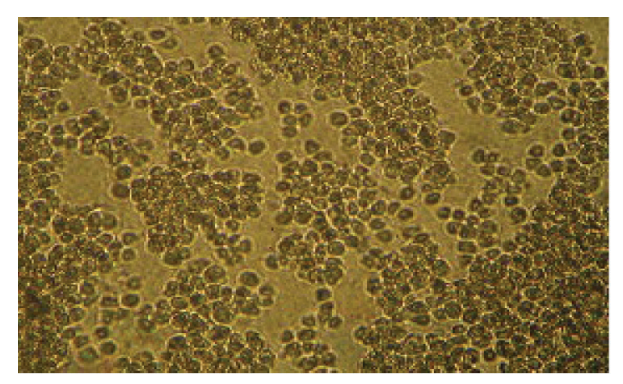

(a)

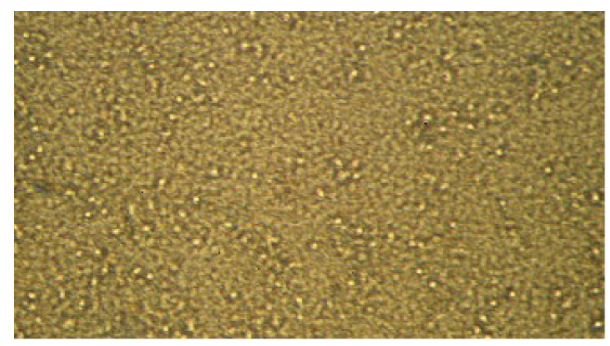

(b)

Figure 2: (a) Tumor cell after $72 \mathrm{~h}$ without $\mathrm{Pd}\left(\mathrm{C}_{19} \mathrm{H}_{20} \mathrm{~N}_{4} \mathrm{O}_{3}\right) \mathrm{Cl}_{2}$ compound. (b) tumor cell after $72 \mathrm{~h}$ with $\mathrm{Pd}\left(\mathrm{C}_{19} \mathrm{H}_{20} \mathrm{~N}_{4} \mathrm{O}_{3}\right) \mathrm{Cl}_{2}$ compound.

to that reported earlier [16]. Briefly, in order to calculate the concentration of each drug that produces a $50 \%$ inhibition of cell growth $\left(\mathrm{IC}_{50}\right), 190 \mathrm{~mL}$ of cell suspension $4 \times 10^{5} \mathrm{cell} / \mathrm{mL}$ ) was exposed to various concentrations of ligand and complexes dissolved in sterile DMSO. The final concentration of DMSO in the growth medium was $2 \%(\mathrm{v} / \mathrm{v})$ or lower, concentrations without effect on cell replication $[17,18]$.

After the incubation periods 72 hours for all cell lines, the cell concentrations were determined both in control and in drug-treated cultures. All experiments were done for six times (see Figure 2).

\section{RESULTS AND DISCUSSION}

\subsection{Preparation for ligand, CDP, and Ti(IV), Zn(II), $\mathrm{Fe}(\mathrm{III})$, and Pd(II) complexes}

The reaction of $\mathrm{Ti}(\mathrm{IV}), \mathrm{Zn}(\mathrm{II}), \mathrm{Fe}(\mathrm{III})$, and $\mathrm{Pd}(\mathrm{II})$ salts with the ligand, $\mathrm{CDP}$, results in the formation of [ML] for $\mathrm{M}=$ Ti(IV), $\mathrm{Zn}(\mathrm{II}), \mathrm{Fe}(\mathrm{III})$, and Pd(II). All complexes are quite stable and could be stored without any appreciable change. All complexes were characterized by several techniques using elemental analyze (C, H, N), FT-IR, electronic spectra, and molar conductance measurements. The elemental analysis data suggest the stoichiometry to be 1:1 [M:L]ratio formation. The molar conductance measurements reveal the presence of 1:1 electrolytic nature complexes. The complexes $\mathrm{Ti}\left(\mathrm{C}_{19} \mathrm{H}_{20} \mathrm{~N}_{4} \mathrm{O}_{3}\right) \mathrm{F}_{4}, \mathrm{Zn}\left(\mathrm{C}_{19} \mathrm{H}_{20} \mathrm{~N}_{4} \mathrm{O}_{3}\right)(\mathrm{OAC})_{2}$, and $\mathrm{Pd}\left(\mathrm{C}_{19} \mathrm{H}_{20} \mathrm{~N}_{4} \mathrm{O}_{3}\right) \mathrm{Cl}_{2}$ do not have sharp melting points but decompose above $237^{\circ} \mathrm{C}, 290^{\circ} \mathrm{C}$, and $331^{\circ} \mathrm{C}$, respectively, but $\mathrm{Fe}\left(\mathrm{C}_{19} \mathrm{H}_{20} \mathrm{~N}_{4} \mathrm{O}_{3}\right) \mathrm{Cl}_{3}$ complex has $153^{\circ} \mathrm{C}-155^{\circ} \mathrm{C}$ melting point. They are insoluble in common organic solvents, 
TABLE 1: 72-hour $\mathrm{IC}_{50}$ and $\mathrm{IC}_{90}$ values $(\mu \mathrm{M})$ obtained for CDP and three CDP complexes.

\begin{tabular}{lcccc}
\hline \multirow{2}{*}{ Complexes } & \multicolumn{2}{c}{$\mathrm{IC}_{50}$ for cell line } & \multicolumn{2}{c}{ IC $\mathrm{C}_{90}$ for cell line } \\
& $\mathrm{K} 562$ & Jurkat & K562 & Jurkat \\
\hline $\mathrm{CDP}$ & $>110$ & $>110$ & - & - \\
$\mathrm{Ti}\left(\mathrm{C}_{19} \mathrm{H}_{20} \mathrm{~N}_{4} \mathrm{O}_{3}\right) \mathrm{F}_{4}$ & $>70$ & $>50$ & $>100$ & $>100$ \\
$\mathrm{Zn}\left(\mathrm{C}_{19} \mathrm{H}_{20} \mathrm{~N}_{4} \mathrm{O}_{3}\right)(\mathrm{OAC})_{2}$ & $>100$ & $>100$ & $>150$ & $>150$ \\
$\mathrm{Fe}\left(\mathrm{C}_{19} \mathrm{H}_{20} \mathrm{~N}_{4} \mathrm{O}_{3}\right) \mathrm{Cl}_{3}$ & $>45$ & $>40$ & $>120$ & $>120$ \\
$\mathrm{Pd}\left(\mathrm{C}_{19} \mathrm{H}_{20} \mathrm{~N}_{4} \mathrm{O}_{3}\right) \mathrm{Cl}_{2}$ & $>36$ & $>33$ & $>85$ & $>80$ \\
\hline
\end{tabular}

such as ethanol, methanol, chloroform, or acetone; however, they are soluble in DMSO and DMF. Their structures were characterized by elemental analysis, ${ }^{1} \mathrm{HNMR}$ and IR. Their elemental analyses are in accord with their proposed formula. The spectral data of the complexes have good relationship with the literature data.

\subsection{Cytotoxicity assays in vitro}

$\mathrm{CDP}$ ligand and $\mathrm{Ti}\left(\mathrm{C}_{19} \mathrm{H}_{20} \mathrm{~N}_{4} \mathrm{O}_{3}\right) \mathrm{F}_{4}, \mathrm{Zn}\left(\mathrm{C}_{19} \mathrm{H}_{20} \mathrm{~N}_{4} \mathrm{O}_{3}\right)$ $(\mathrm{OAC})_{2}, \quad \mathrm{Fe}\left(\mathrm{C}_{19} \mathrm{H}_{20} \mathrm{~N}_{4} \mathrm{O}_{3}\right) \mathrm{Cl}_{3}$, and $\mathrm{Pd}\left(\mathrm{C}_{19} \mathrm{H}_{20} \mathrm{~N}_{4} \mathrm{O}_{3}\right) \mathrm{Cl}_{2}$ complexes have been tested against two human cancer cell lines: K562 and Jurkat. The $\mathrm{IC}_{50}$ cytotoxicity values of the complexes were compared to those found for the starting organic bases as well as for some of the anticancer agents used nowadays, that are cisplatin and oxaplatin compounds [19].

The general method used for testing on antitumor properties of these compounds is the standard testing method that has been previously described in greater detail.

After preincubation lasting for 12 hours at $37^{\circ} \mathrm{C}$ in a $5 \% \mathrm{CO}_{2}$ atmosphere and $100 \%$ humidity, the tested compounds in the concentration ranges of $0.1-$ $250 \mu \mathrm{M}$ for CDP, of $0.1-150 \mu \mathrm{M}$ for $\mathrm{Ti}\left(\mathrm{C}_{19} \mathrm{H}_{20} \mathrm{~N}_{4} \mathrm{O}_{3}\right) \mathrm{F}_{4}$, of $0.1-100 \mu \mathrm{M}$ for $\mathrm{Zn}\left(\mathrm{C}_{19} \mathrm{H}_{20} \mathrm{~N}_{4} \mathrm{O}_{3}\right)(\mathrm{OAC})_{2}$, of $0.1-$ $200 \mu \mathrm{M}$ for $\mathrm{Fe}\left(\mathrm{C}_{19} \mathrm{H}_{20} \mathrm{~N}_{4} \mathrm{O}_{3}\right) \mathrm{Cl}_{3}$, and of $0.1-97 \mu \mathrm{M}$ for $\mathrm{Pd}\left(\mathrm{C}_{19} \mathrm{H}_{20} \mathrm{~N}_{4} \mathrm{O}_{3}\right) \mathrm{Cl}_{2}$ were added. The incubation lasted for 72 hours and at the end of this period $\mathrm{IC}_{90}$ and $\mathrm{IC}_{50}$ of the dead cells and live cells were measured by trypan blue. The mechanism by which these complexes act as antitumor agents is apoptosis. $\mathrm{IC}_{90}$ and $\mathrm{IC}_{50}$ values that are the compounds concentrations lethal for $90 \%$ and $50 \%$ of the tumor cells were determined both in control and in compounds concentrations lethal for both in compoundstreated cultures. The compounds were first dissolved in DMSO and then filtrated. The corresponding 50\% and $90 \%$ inhibitory doses (IC50 and IC90) values are shown in Table 1.

\section{CONCLUSION}

It is clear from the above discussion that $\mathrm{Ti}(\mathrm{IV}), \mathrm{Zn}$ (II), $\mathrm{Fe}(\mathrm{III})$ and $\mathrm{Pd}(\mathrm{II})$ complexes and CDP ligand offer a new outlook for chemotherapy. The results of antitumor activity show that the metal complexes exhibit antitumor properties and it is important to note that they show enhanced inhibitory activity compared to the parent ligand. The mechanism by which these complexes act as antitumor agents is apoptosis. It has also been proposed that concentration plays a vital role in increasing the degree of inhabitation.

\section{ACKNOWLEDGMENTS}

We gratefully acknowledge the financial support from the Research Council of Ardabil Islamic Azad University and many technical supports that are provided by Tarbiat Modarres University.

\section{REFERENCES}

[1] X. F. Luo, X. Hu, X. Y. Zhao, S. H. Goh, and X. D. Li, "Miscibility and interactions in blends and complexes of poly(4-methyl-5-vinylthiazole) with proton-donating polymers," Polymer, vol. 44, no. 18, pp. 5285-5291, 2003.

[2] A. S. N. Murthy and A. R. Reddy, "Electronic absorption spectroscopic studies of enolimine-ketoamine equilibria in Schiff bases," Journal of Chemical Sciences, vol. 90, no. 6, pp. 519-526, 1981.

[3] V. Razakantoanina, N. K. P. Phung, and G. Jaureguiberry, "Antimalarial activity of new gossypol derivatives," Parasitology Research, vol. 86, no. 8, pp. 665-668, 2000.

[4] R. E. Royer, L. M. Deck, T. J. Vander Jagt, et al., "Synthesis and anti-HIV activity of 1,1'-dideoxygossypol and related compounds," Journal of Medicinal Chemistry, vol. 38, no. 13, pp. 2427-2432, 1995.

[5] M. R. Flack, R. G. Pyle, N. M. Mullen, et al., "Oral gossypol in the treatment of metastatic adrenal cancer," The Journal of Clinical Endocrinology \& Metabolism, vol. 76, no. 4, pp. 10191024, 1993.

[6] R. Baumgrass, M. Weiwad, F. Erdmann, et al., "Reversible inhibition of calcineurin by the polyphenolic aldehyde gossypol," Journal of Biological Chemistry, vol. 276, no. 51, pp. 47914-47921, 2001.

[7] M. B. Teimouri and R. Bazhrang, "Shaken not stirred: a facile synthesis of 1,4-bis(furo[2,3,d]-pyrimidine-2,4(1H,3H)dione-5-yl)benzenes by one-pot reaction of isocyanides, $N, N^{\prime}$-dimethylbarbituric acid, and terephthaldialdehyde," Bioorganic \& Medicinal Chemistry Letters, vol. 16, no. 14, pp. 3697-3701, 2006.

[8] M. B. Teimouri, "One-pot three-component reaction of isocyanides, dialkyl acetylenedicarboxylates and phthalhydrazide: synthesis of highly functionalized $1 H$-pyrazolo[1,2b] phthalazine-5,10-diones," Tetrahedron, vol. 62, no. 47, pp. 10849-10853, 2006.

[9] J. V. Metzger, A. R. Katritzky, W. Rees, and K. T. Potts, Eds., Comprehensive Heterocyclic Chemistry, vol. 6, Pergamon, Oxford, UK, 1984.

[10] J. M. Grevy, F. Tellez, S. Bernés, H. Nöth, R. Contreras, and N. Barba-Behrens, "Coordination compounds of thiabendazole with main group and transition metal ions," Inorganica Chimica Acta, vol. 339, pp. 532-542, 2002.

[11] A. Bernalte-García, F. J. García-Barros, F. J. Higes-Rolando, and F. Luna-Giles, "Coordination chemistry of thiazoline/thiazolidine derivatives. I: crystal structure of 2-(2pyridyl)imino- $N$-(2-thiazolin-2-yl)thiazolidine (PyTT) and study of its interaction with nickel(II)," Polyhedron, vol. 18, no. 22, pp. 2907-2912, 1999. 
[12] K. Lemma, J. Berglund, N. Farrell, and L. I. Elding, "Kinetics and mechanism for reduction of anticancer-active tetrachloroam(m)ine platinum(IV) compounds by glutathione," Journal of Biological Inorganic Chemistry, vol. 5, no. 3, pp. 300306, 2000.

[13] M. J. M. Campbell, "Transition metal complexes of thiosemicarbazide and thiosemicarbazones," Coordination Chemistry Reviews, vol. 15, no. 2-3, pp. 279-319, 1975.

[14] S. Padhyé and G. B. Kauffman, "Transition metal complexes of semicarbazones and thiosemicarbazones," Coordination Chemistry Reviews, vol. 63, pp. 127-160, 1985.

[15] B. Erwin and C. Omoshile, "Hydrogen isotope exchange in $\mathrm{Pt}^{\mathrm{II}}$-thiazole complexes," Journal of the Chemical Society Perkin Transactions, vol. 2, pp. 1333-1338, 1995.

[16] G. Zhao, H. Lin, S. Zhu, H. Sun, and Y. Chen, "Dinuclear palladium(II) complexes containing two monofunctional $[\mathrm{Pd}(\mathrm{en}) \text { (pyridine) } \mathrm{Cl}]^{+}$units bridged by Se or S. Synthesis, characterization, cytotoxicity and kinetic studies of DNAbinding," Journal of Inorganic Biochemistry, vol. 70, no. 3-4, pp. 219-226, 1998.

[17] J. Ishida, H.-K. Wang, K. F. Bastow, C.-Q. Hu, and K.-H. Lee, "Antitumor agents 201. ${ }^{1}$ Cytotoxicity of harmine and $\beta$ carboline analogs," Bioorganic \& Medicinal Chemistry Letters, vol. 9, no. 23, pp. 3319-3324, 1999.

[18] J.-K. Son, L.-X. Zhao, A. Basnet, et al., "Synthesis of 2,6-diarylsubstituted pyridines and their antitumor activities," European Journal of Medicinal Chemistry, vol. 43, no. 4, pp. 675-682, 2008.

[19] Y.-S. Kim, R. Song, H. C. Chung, M. J. Jun, and Y. S. Sohn, "Coordination modes vs. antitumor activity: synthesis and antitumor activity of novel platinum(II) complexes of $N$ substituted amino dicarboxylic acids," Journal of Inorganic Biochemistry, vol. 98, no. 1, pp. 98-104, 2004. 


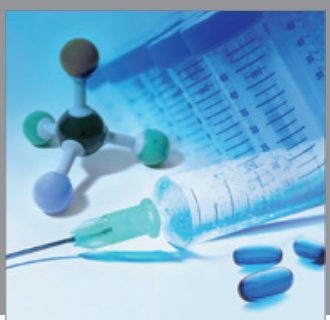

International Journal of

Medicinal Chemistry

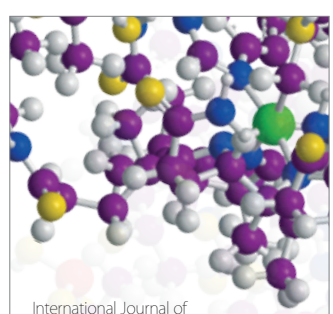

Carbohydrate Chemistry

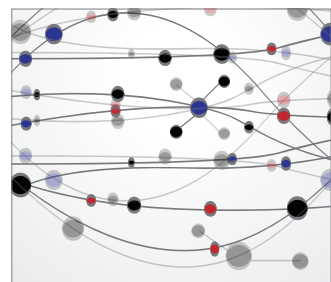

The Scientific World Journal
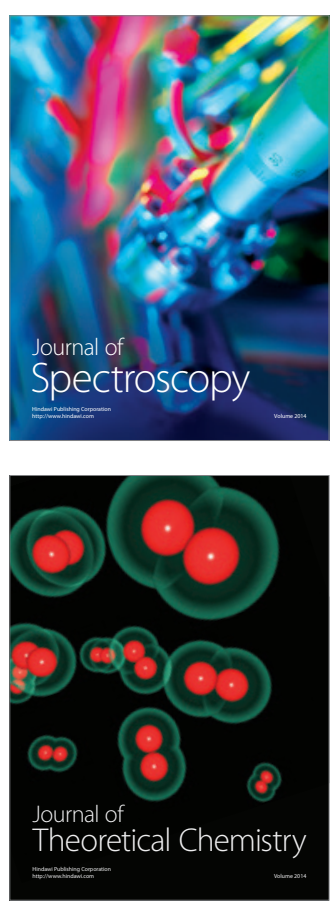
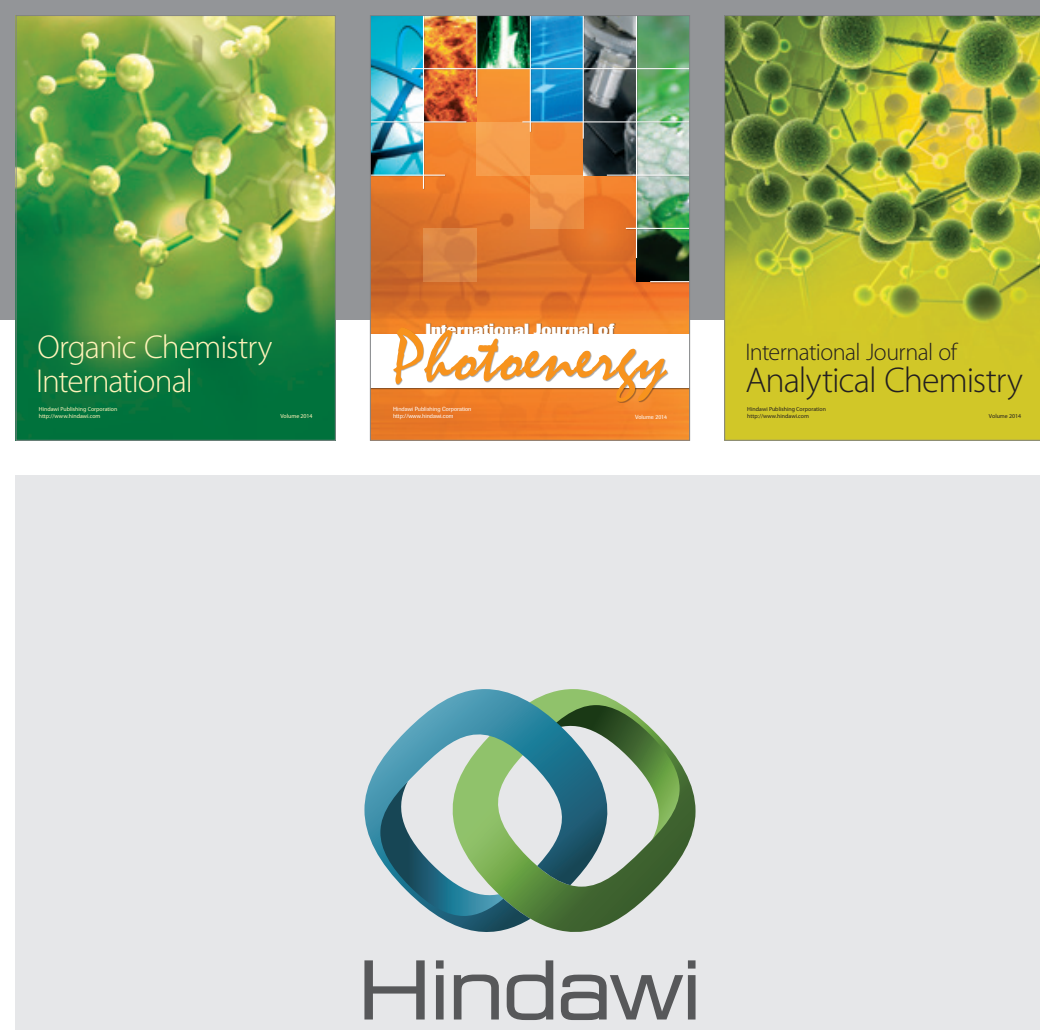

Submit your manuscripts at

http://www.hindawi.com
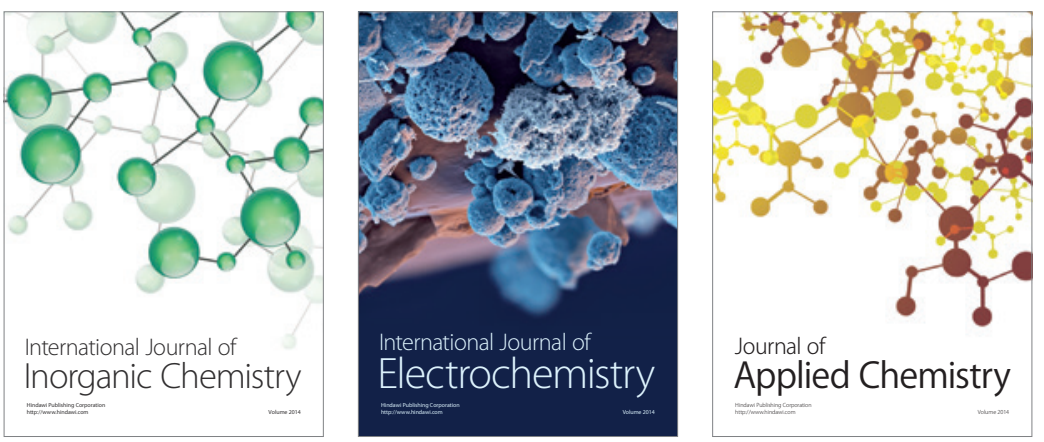

Journal of

Applied Chemistry
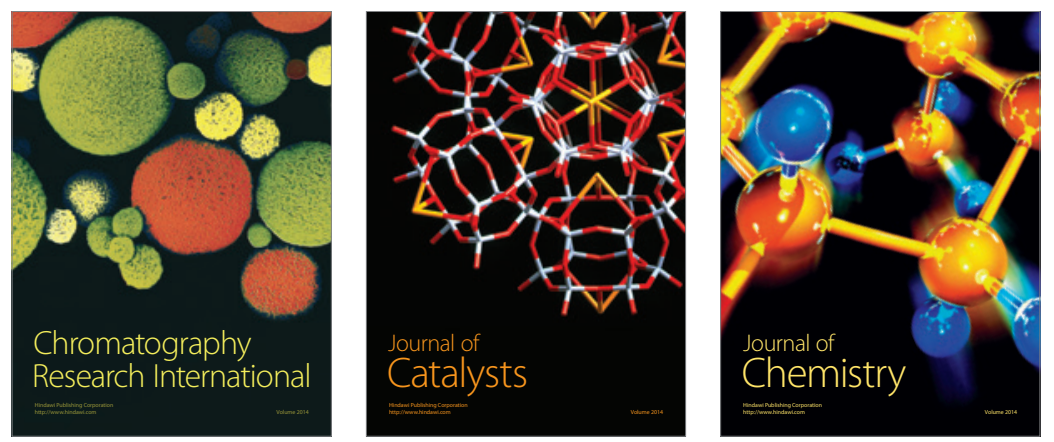
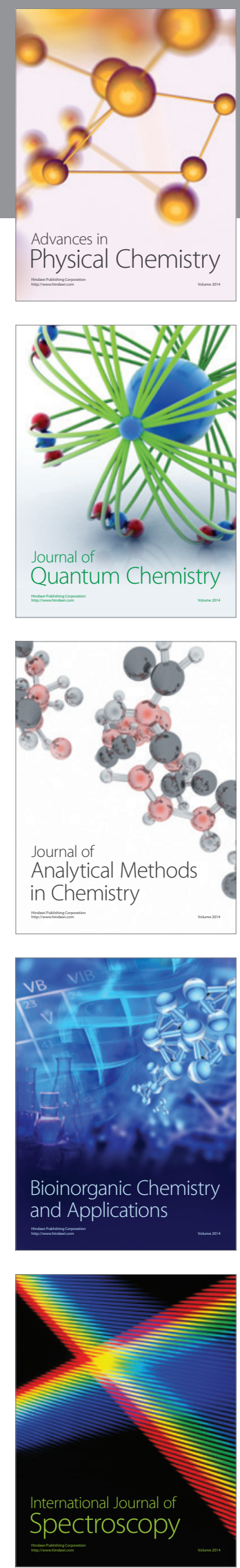